\title{
Distribution Maps of the Different Levels of Elemental Concentrations Accumulated by the Lichen in the Northeast of Algeria
}

\author{
Fatima Adjiri $^{1 *}$ Messaoud Ramdani ${ }^{2}$ \\ 1.Department of Plant Biology and Ecology, Faculty of Nature and Life Sciences, University Ferhat Abbas Setif \\ $-1,19000$, Algeria \\ Laboratory of Natural Resource Valorisation, SNV Faculty, Ferhat Abbas University Setif-1, 19000, Algeria \\ 2.Department of Plant Biology and Ecology, Faculty of Nature and Life Sciences, University Ferhat Abbas Setif \\ $-1,19000$, Algeria \\ Laboratory of Natural Resource Valorisation, SNV Faculty, Ferhat Abbas University Setif-1, 19000, Algeria \\ *E-mail of the corresponding author: adjirifatima@gmail.com
}

\begin{abstract}
An evaluation of environmental pollution in the region of Bordj Bou Arreridj (BBA), Algeria according to metallic trace elements has been carried out, to determine the levels of the 10 elements accumulated in lichens and the different sources found in the region. A total of 192 samples of Xanthoria parietina lichen were collected over an area of $3920.42 \mathrm{~km}^{2}$. Sampling sites include urban sites, rural sites, green parks, sites near high traffic streets and industrial enterprises. The lichen samples were analyzed by FAAS for the ten elements and their concentrations were mapped. Concentrations of $\mathrm{Pb}, \mathrm{Cd}, \mathrm{Sb}$ and $\mathrm{Zn}$ were higher at urban sites and increased with proximity to highways and industrial areas. These results suggest that the composition of lichen elements is strongly affected by road traffic. While the sources of the elements $\mathrm{Co}, \mathrm{Ni}, \mathrm{Fe}, \mathrm{Mn}$ and $\mathrm{Cr}$ probably come from dust from quarrying and contaminated soil deposits in particular, to the north and west of the region. This mapping of metal pollution can establish the first biological monitoring network in the study area.
\end{abstract}

Keywords: Biomonitoring of lichens, Metallic elements, Pollution sources, Distribution maps, BBA.

DOI: $10.7176 / \mathrm{JEES} / 12-2-03$

Publication date: February $28^{\text {th }} 2022$

\section{Introduction}

Emissions such as the elements have long been recognized as potential threats to the environment and human health (Azimi et al. 2005). In this problem, the metallic trace elements (MTE) that are mentioned in the literature constitute the most important category of atmospheric pollutants. (Pacyna \& Pacyna 2001; Gombert et al. 2005; Gouzy \& Ducos 2008; Rauch \& Pacyna 2009; Aslan et al.2011; Sen \& Peucker-Ehrenbrink 2012; Agnan et al. 2013).

Air pollution monitoring is essential in order to control air quality and to be able to identify and reduce anthropogenic sources (Garrec \& Van Haluwyn 2002). Road traffic and dust deposits are two of the most serious sources of air pollution (Wu et al. 2020). In order to follow this pollution with the measurement of MTE in the atmosphere, physical and chemical methods as well as biological methods are available (De Temmerman et al. 2004). Physico-chemical measurements are objective and precise methods, but the use of this technical equipment is not widespread for economic reasons, compared to biological methods (Conti \& Cecchetti 2001; Wolterbeek 2002; Tian et al. 2015).

Plants are known to be very suitable organisms for biological monitoring of air quality and they can be very effective in detecting environmental changes (Markert et al. 1997; Mulgrew \& Williams 2000).

The use of lichens as bio-monitors in air pollution biological monitoring studies evolved from long-standing observations of the relationships between air pollution and the presence of lichen species (Wolterbeek et al. 2003; Rzepka \& Cuny 2008; Loppi 2019). This use offers the means to carry out preliminary estimates of the propagation of this pollution, the location and identification of pollution sources, and the method of mapping pollution levels in a given area (Sloof \& Wolterbeek 1993; Loppi et al. 2004). Spatio-temporal maps of atmospheric pollution levels are carried out to monitor MTE near sources of road and industrial emissions (Cuny 2012). The analysis of pollutants in atmospheric deposits is facilitated by the bioaccumulation method, due to the absence of a root system; lichens take up and accumulate concentrations of MTE in their thalli from wet and dry deposition (Shukla et al. 2014; Sett \& Kundu 2016).

The most common epiphytic lichen, Xanthoria parietina, is the species most used in biological monitoring studies (Nash 2008), because of its ability to accumulate high amounts of MTE in polluted areas (Nimis et al. 2001; Scerbo et al. 2002; Dörter et al. 2020). This species was chosen as the target organism of the present study in the passive biological surveillance for the accumulation of MTE in the region of Bordj Bou Arreridj (BBA) in northeast Algeria. The study was carried out with the aim of establishing distribution maps of MTE 
concentrations within urban, industrial and rural sites at BBA and identify the sources of air pollution emissions in the region and their impact.

\section{Materials and methods}

\subsection{Study area}

The sampling was carried out in the region of BBA located in the North East of Algeria, which has a total area of $3920.42 \mathrm{~km}^{2}$. Sampling strategies were put in place taking into account topography, urbanization and industry. Was carried out in the region of more than 658,968 inhabitants, is centered in the east and the center of the region, where high levels of air pollutants occur mainly emitted by road traffic and industry. In contrast, many mountainous sites are sparsely populated, devoid of local sources of atmospheric pollution, but the harvest has an environmental impact.

The region is determine by a semi-arid continental climate, more humid on the north side in mountainous sites with higher elevations and drier on the south side.

\subsection{Sample processing and analysis}

Lichen samples were collecting from 34 sites near main roads, public gardens, rural sites, urban sites and industrial areas (Figure 1). Lichen samples were taken naturally in situ from tree trunks. Lichen thalli are collected from at least ( 3 to 6 ) trees at a height of more than $1 \mathrm{~m}$ above the ground to avoid any contamination that could influence the composition of the sample (Nimis et al. 2002).

The collected samples are kept in paper bags and are referenced by all the necessary indications of site and sampling, then are transported to the laboratory in a clean environment for processing and mineralization. Xanthoria parietina thalli were digesting in the laboratory and under aseptic conditions (Picardie 2004). The most widely used MTE solubilization method is mineralization by acid attack. It is carried out in a firm and hot environment at $150^{\circ} \mathrm{C}$ to avoid loss of volatile elements. All steps are performed in Teflon containers to prevent moisture absorption.

Lichen samples were washed with distilled water to remove plant debris using plastic tweezers and a ceramic knife, after rinsing, the thalli were put in filter papers and oven dried for 72 hours. The dried thalli were ground into a fine powder so as to promote the dissolution of the elements to be analyzed. The powder obtained after grinding is calcined in a muffle furnace, the temperature of which is gradually increased to $500{ }^{\circ} \mathrm{C}$ from 02 until 04 hours, using quartz capsules. Then the fine powder is placed in an acid solution; about $0.5 \mathrm{~g}$ of dry plant material with $5 \mathrm{ml}$ of hydrofluoric acid (HF $40 \%)$ and $1.5 \mathrm{ml}$ of perchloric acid $\left(\mathrm{ClHO}_{4} 70 \%\right)$. The solution is homogenized before heating to $160^{\circ} \mathrm{C}$, until the solution has completely evaporated. After almost total evaporation, a second dissolution is carried out by adding $0.5 \mathrm{ml}$ of nitric acid $\left(65 \% \mathrm{HNO}_{3}\right)$ and $5 \mathrm{ml}$ of distilled water. The solution is left to stand for $30 \mathrm{~min}$ in the refrigerator at a temperature of $4{ }^{\circ} \mathrm{C}$, then put back into solution on a hot plate at $60^{\circ} \mathrm{C}$ for one hour. The resulting mixture is transferred to a $50 \mathrm{ml}$ flask for filtration adjusting the volume with distilled water.

Then these concentrations of the trace metal elements $\mathrm{Cd}, \mathrm{Cu}, \mathrm{Cr}, \mathrm{Co}, \mathrm{Fe}, \mathrm{Mn}, \mathrm{Ni}, \mathrm{Pb}, \mathrm{Sb}$ and $\mathrm{Zn}$ are determined by flame atomic absorption spectrophotometry (FAAS).

\subsection{Data analysis}

The concentrations of elements accumulated by $X$. parietina at the levels of urban sites, sites near roads, rural sites and industrial areas of the BBA region were mapping from the coordinates of the sampling points by the ArcMap 10.5 software. The maps were using to represent the surface distribution of metal pollution in the study area. The results of the analyzed lichens were evaluated using Statistica 10 software. 


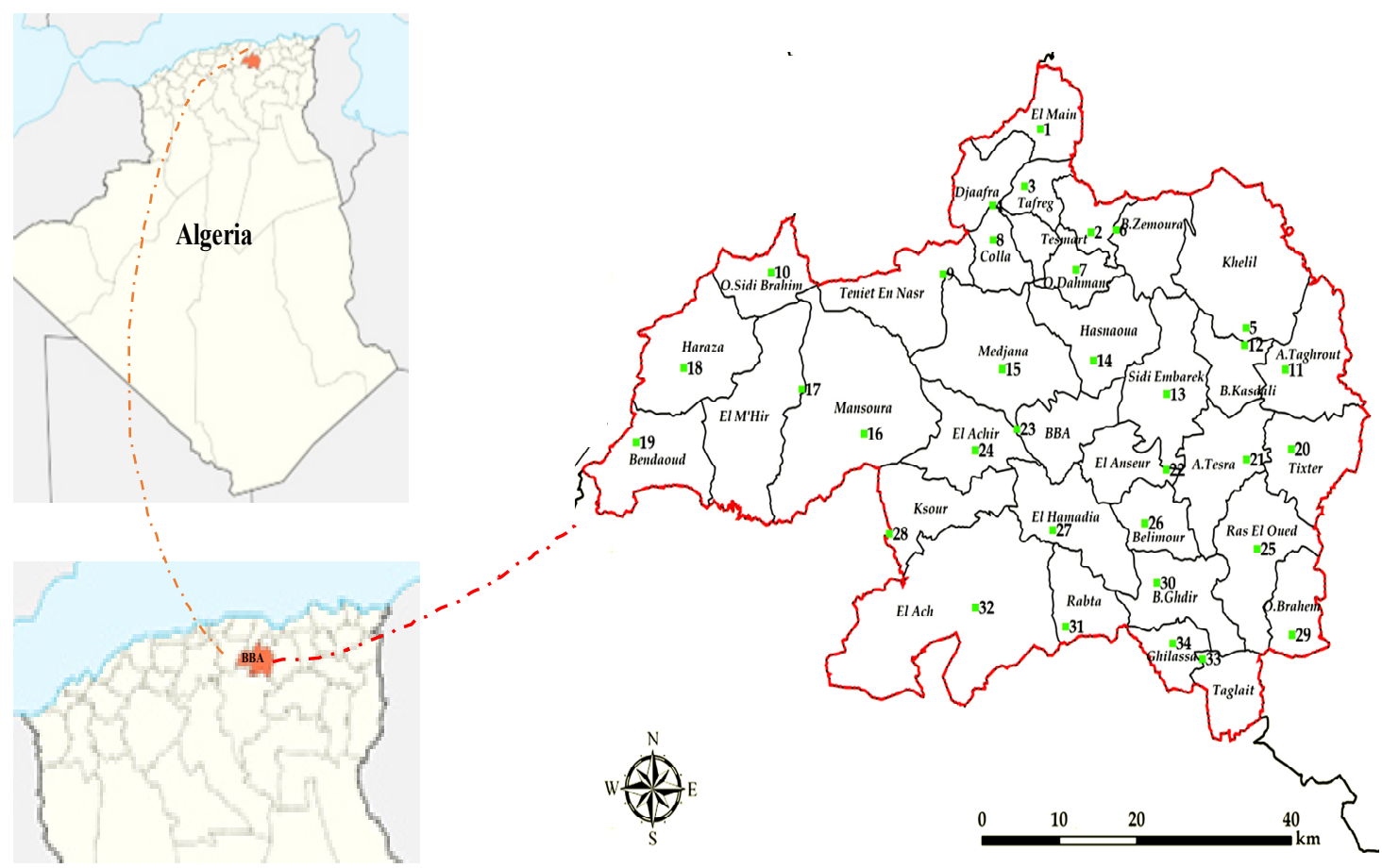

Figure 1: sites sampled in the BBA region North-Est of Algeria

\section{Results and discussion}

\subsection{Variation in MTE concentrations}

A principal component statistical analysis is performe on all the sites to determine the variability of the concentrations of MTE estimated in the thalli of X. parietina and the relationship of these concentrations with the sites studied. The mean concentrations of ten elements in the sites sampled at the level of the BBA region varied between $3.25 \mathrm{mg} / \mathrm{kg}$ and $43184.38 \mathrm{mg} / \mathrm{kg}$ depending on the location of the site (Table 1).

It is noted that all the concentrations of MTE estimated in the thalli exceed the certified standard, except the $\mathrm{Pb}$ concentrations are lower than the certified standard or the minimum values have been recorded in rural sites. While, Iron has the highest average concentration in the entire study region $(43184.88 \pm 16373.66 \mathrm{mg} / \mathrm{kg})$.

The coefficient of variation (CV) of MTE concentrations in the thalli measured is varied between $18.2 \%$ and $62 \%$, high $\mathrm{CV}$ values were observed for $\mathrm{Ni}, \mathrm{Mn}, \mathrm{Pb}, \mathrm{Cu}$ and $\mathrm{Fe}$. A significant variability noted by the concentration of $\mathrm{Ni}(62 \%)$ with an average of $(64.96 \pm 40.32)$, while $\mathrm{Sb}$ and $\mathrm{Cd}$ are the least abundant in the thalli and also present an absence of variability $19.10 \%$ and $18.2 \%$ respectively. The average variation of the ten elements analyzed is $35.17 \%$.

Table 1. Mean of the concentrations of the elements ( $\mathrm{mg} / \mathrm{kg}$ ); median; standard deviations; max and min values found in X. parietina in the BBA region are expressed as the mean coefficient of variation $(\mathrm{CV})$ and the certified values and standard deviations (CRM 482) by the FAAS (Quevauviller et al., 1996).

\begin{tabular}{|l|l|l|l|l|l|}
\hline Element & Mean \pm SD & Median & Min-Max & CV(\%) & Certified values $\pm S D$ \\
\hline $\mathrm{Cd}$ & $3.25 \pm 0.62$ & 3 & $2-5$ & 18.2 & $0.56 \pm 0.02$ \\
\hline $\mathrm{Cr}$ & $313.44 \pm 97.27$ & 327.89 & $127.9-472.1$ & 31.1 & $4.12 \pm 0.15$ \\
\hline $\mathrm{Cu}$ & $49.81 \pm 19.28$ & 51 & $23-87$ & 38.8 & $7.03 \pm 0.19$ \\
\hline $\mathrm{Co}$ & $556.48 \pm 152.59$ & 586.09 & $254.3-814.8$ & 27.4 & $0.32 \pm 0.03$ \\
\hline $\mathrm{Fe}$ & $43184.38 \pm 16373.66$ & 42950 & $7000-73000$ & 37.9 & $804 \pm 16$ \\
\hline $\mathrm{Mg}$ & $671.88 \pm 312.36$ & 550 & $300-1300$ & 46.5 & $33 \pm 0.5$ \\
\hline $\mathrm{Ni}$ & $64.96 \pm 40.32$ & 65.77 & $3.3-133.4$ & 62 & $2.47 \pm 0.07$ \\
\hline $\mathrm{Pb}$ & $98.44 \pm 39.54$ & 96 & $6-206$ & 40.1 & $40.9 \pm 1.4$ \\
\hline $\mathrm{Sb}$ & $186.75 \pm 35.73$ & 185.5 & $93.00-253.00$ & 19.1 & $0.35 \pm 0.09$ \\
\hline $\mathrm{Zn}$ & $476.63 \pm 145.91$ & 438.08 & $323.90-983.52$ & 3.6 & $100.6 \pm 2.2$ \\
\hline
\end{tabular}

\subsection{MTE distribution maps}

A cluster analysis was using, in order to map the levels of metallic pollution by the atmosphere in the urban area of BBA. This analysis revealed two groups of elements (Figure 2). In each small group, one element was chosen to represent that group. The distribution maps of concentrations measured in the lichen thalli X. parietina are 
represented in the ten metallic trace elements $(\mathrm{Cd}, \mathrm{Cu}, \mathrm{Cr}, \mathrm{Co}, \mathrm{Fe}, \mathrm{Mn}, \mathrm{Ni}, \mathrm{Pb}, \mathrm{Sb}$, and $\mathrm{Zn})$.

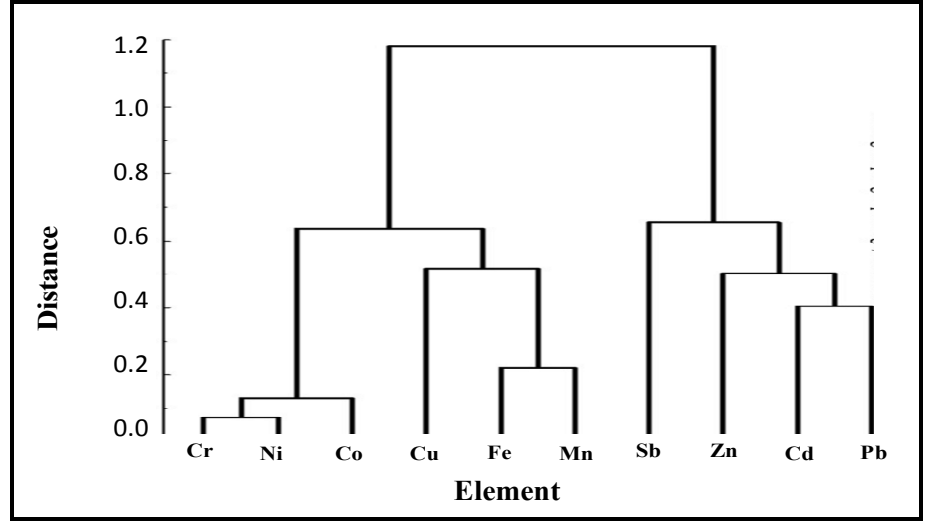

\subsubsection{Concentration of Lead (Pb)}

Figure 2: Classification of MTE in X. parietina thalli

Anthropogenic lead emissions have long been dominated by road traffic, due to the presence of $\mathrm{Pb}$ in gasoline (Loppi et al. 2004; Li et al. 2012 ; Dörter et al. 2020), but this contribution of gasoline to atmospheric Pb is decreasing due to the increased use of unleaded gasoline (Yenisoy-Karakas \& Tuncel 2004). However, other industrial activities that can be major sources of this toxic element in the environment (Agnan et al. 2013). In the study area, the distribution of the highest $\mathrm{Pb}$ values are recorded in urban sites that are close to highwayssuch as Ain Taghrout $(206 \mathrm{mg} / \mathrm{kg})$, Medjana $(173 \mathrm{mg} / \mathrm{kg})$, Tixter $(169 \mathrm{mg} / \mathrm{kg})$ and Hasnaoua $(136 \mathrm{mg} / \mathrm{kg})$ sites. While, minimum concentrations are observed in rural sites away from main roads (Figure $3 \mathrm{a}$ ). The high $\mathrm{Pb}$ values in the study area are mainly related to traffic, due to the use of many older cars.

\subsubsection{Concentration of Cadmium (Cd)}

$\mathrm{Cd}$ concentrations are around $3 \mathrm{mg} / \mathrm{kg}$ in most of the sites located to the south and west to the north of the BBA region. The maximum concentrations of this element are observed near major roads and industrial activities (Figure $3 \mathrm{~b}$ ). $\mathrm{Cd}$ is an element, used in vehicle components industry (Ouali-Alami et al. 2014), which confirms that the contamination in urban sites at BBA by this element is of anthropogenic origin from various vehicular and industrial emissions.

\subsubsection{Concentration of Antimony (Sb)}

In the literature, authors attribute the high levels of $\mathrm{Sb}$ mainly to road traffic, waste incineration and the production of accumulators, rubber additives and in paints (Azimi et al. 2005; Tian et al. 2015). This contamination by $\mathrm{Sb}$ extends to rural stations where the maximum concentration is recorded in Ouled-Dahmane $(253 \mathrm{mg} / \mathrm{kg})$, probably coming from sources located outside the borders of the study area, as reported in France by Agnan et al. (2013). It is noted that the results of the distribution map of the concentrations of Sb at BBA are similar to those of the results of the distribution maps of $\mathrm{Pb}$ and $\mathrm{Cd}$ (Figure $3 \mathrm{c}$ ). These high levels of $\mathrm{Sb}$ in urban and industrial sites, so they seem to be related to road traffic emissions (Yenisoy-Karakas \& Tuncel 2004).

\subsubsection{Concentration of Zinc (Zn)}

These high values are due to road traffic as has been suggested in the literature (Scerbo et al. 2002; Conti 2008; Kinalioglu et al. 2010), but also this element is widely used in the manufacture of metals, production of cement, steel, plastic and paints (Lin et al. 2002; Demiray et al. 2012). Another source of Zn-related pollution that can be a threat in the region is agricultural activity, through the use of fertilizers and pesticides that produce relatively high zinc concentrations (Mulgrew \& Williams 2000; Pignata et al. 2002). The highest concentrations of Zn are observed at urban sites close to main roads, and around industrial sites (Figure 3d). There is no metallurgical industry in BBA, the production of cement and plastics can be a point source that emits pollutants in significant quantities into the atmosphere. Moderate concentrations have been found in agricultural sites far from pollution sources, these concentrations may be due to the use of fertilizers.

\subsubsection{Concentration of Iron ( Fe)}

Iron is one of the main components of soil minerals, thus, this element is used as building materials (Nimis et al. 2001; Aslan et al. 2011; Demiray et al. 2012; Parzych et al. 2016; Francovà et al. 2017). The high rate of Fe in our sites is linked to geographical factors since Iron is a soil element which undergoes significant bioaccumulation in the thalli. The highest values were also distributed in the North and West of the region, these values gradually decrease towards the South and East where the lowest value was recorded (Figure 3e). The second explanation for the high rate in the thalli is due to the accumulation of dust from anthropological activities (cement industry, quarrying, brick making and gravel processing) which are frequently found in the BBA region (Branquinho et al. 1997; Branquinho et al. 2008; Aslan et al. 2011). The Fe values analyzed in the thalli of $X$. parietina are varied between $7000 \mathrm{mg} / \mathrm{kg}$ and $73000 \mathrm{mg} / \mathrm{kg}$ with a median of $42950 \mathrm{mg} / \mathrm{kg}$. 


\subsubsection{Concentration of Manganese (Mn)}

Manganese in the air is of natural origin, it is an important element derived from the soil. Thus, this element is used in the production of batteries and alloys (Markert et al. 1997; Yenisoy-Karakas \& Tuncel 2004; Dron et al. 2016; Parzych et al. 2016). The highest Mn concentrations were distributed north and west of BBA (Figure 3f). Thus, this element is used in the production of batteries and alloys (Azimi et al. 2005). This may be the reason for the high concentrations of $\mathrm{Mn}$ found in the region especially to the north and west of BBA. The Mn values obtained from this analysis are between $(300 \mathrm{mg} / \mathrm{kg}-1300 \mathrm{mg} / \mathrm{kg})$ with a median of $550 \mathrm{mg} / \mathrm{kg}$.
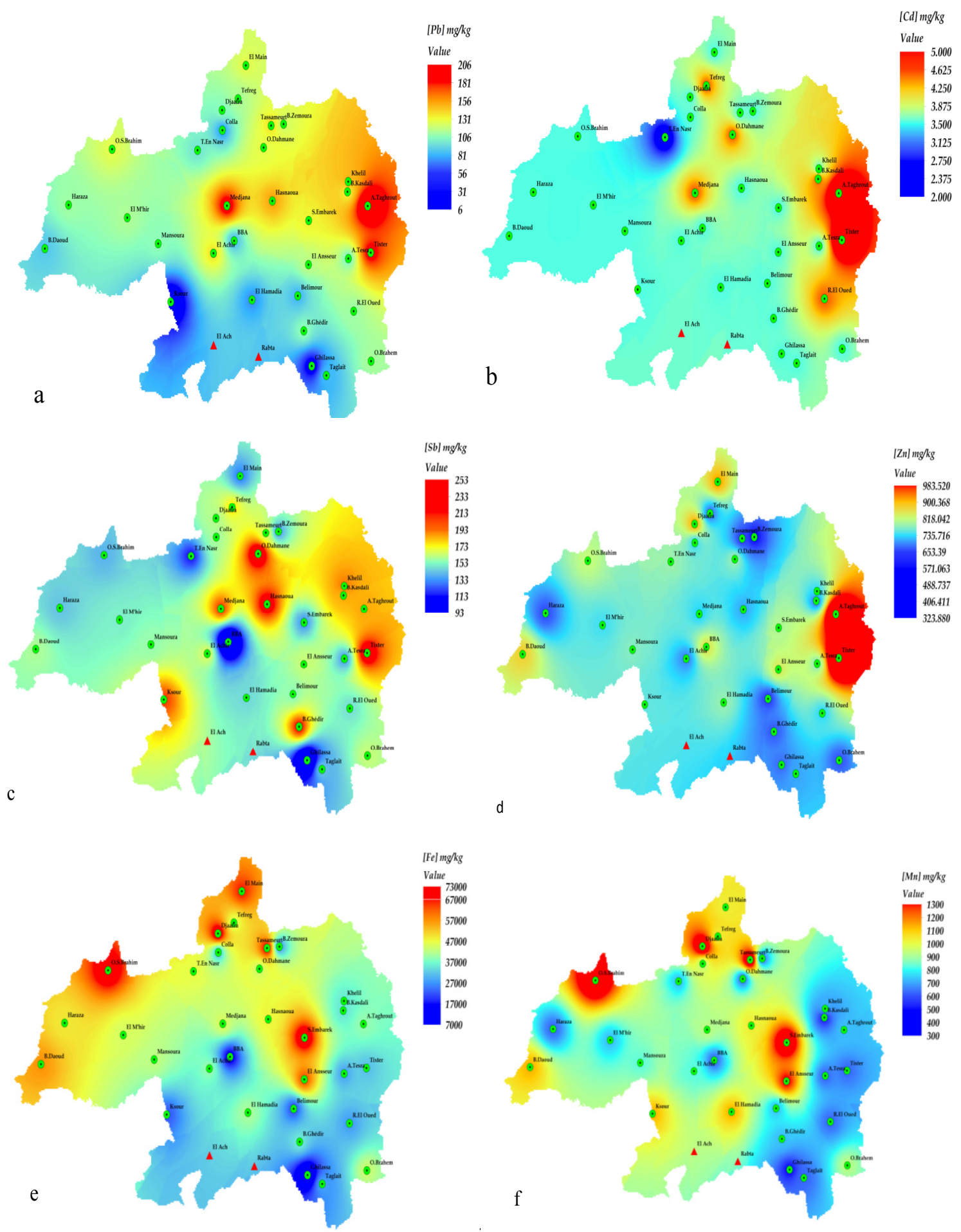

Figure 3: Distribution map of element concentrations (a) lead, (b) cadmium, (c) antimony, (d) zinc, (e) iron, (f) manganese (g) copper (h) cobalt, (i) chromium and (j) nickel $(\mathrm{mg} / \mathrm{kg})$ in the lichen X. parietina in the BBA region north-est of Algeria 


\subsubsection{Concentration of Copper $(\mathrm{Cu})$}

The distribution of $\mathrm{Cu}$ concentrations in the region is similar to those of $\mathrm{Fe}$ and $\mathrm{Mn}$, the low values of which are located to the south and east of the BBA region. While the highest values are distributed to the north and west, particularly in agricultural sites (Figure 3g). Several studies carried out in the world show that $\mathrm{Cu}$ is an element that comes not only from road traffic and the metallurgical industry but also from agricultural activities (Pignata et al. 2002; Tian et al. 2015; Parzych et al. 2016). This suggests that the use of fertilizers may be a source of $\mathrm{Cu}$ contamination in agricultural sites in the study area. We can suggest another source of $\mathrm{Mn}$ in the region, in particular, in the sites of El M'hir, Mansoura, El Ansseur, El Achir and Ouled Sidi-Brahim, which includes rail transport.

\subsubsection{Concentration of Cobalt (Co)}

The results of the Cobalt distribution map show that the high concentrations are distributed west of the BBA region (Figure 3h). Dust from quarrying and manufacturing of building materials may be the reason in the region studied (Dörter et al. 2020). The Co values are varied between $254.30 \mathrm{mg} / \mathrm{kg}$ and $814.80 \mathrm{mg} / \mathrm{kg}$, the median value is $586.09 \mathrm{mg} / \mathrm{kg}$.

\subsubsection{Concentration of Chromium (Cr)}

In the study region, the highest accumulation of $\mathrm{Cr}$ is observed in the western parts, particularly at agricultural sites (Figure 3i). The high level of concentrations of this element in agricultural sites can be partly explained by the contribution to its presence in the soil (Scerbo et al. 2002). The range of chromium concentrations measured in the thalli of Xanthoria parietina being between $127.90 \mathrm{mg} / \mathrm{kg}$ and $472.11 \mathrm{mg} / \mathrm{kg}$ with a median value of $327.89 \mathrm{mg} / \mathrm{kg}$.

\subsubsection{Concentration of Nickel (Ni)}

In the study region, the highest $\mathrm{Ni}$ concentrations were found in the West (Figure $3 \mathrm{j}$ ). The high rate of this element may be due to pollution transported from neighboring regions. These concentrations decrease towards the eastern stations where the lowest levels were observe at industrial and urban sites. Ni contents in lichen thalli vary between $3.72 \mathrm{mg} / \mathrm{kg}$ and $133.40 \mathrm{mg} / \mathrm{kg}$ with a median value of $65.77 \mathrm{mg} / \mathrm{kg}$.

The distributions of the analyzed $\mathrm{Cr}$, Co and Ni elements represented on the maps (Figs. $3 \mathrm{~h}-3 \mathrm{i} \& 3 \mathrm{j}$ ) are similar. Nevertheless, there is one possibility that would explain the high levels of these three elements at sites in the west of the region that are characterized by agricultural and grazing activities: probably the element composition of western BBA lichens is strongly affected by dust deposition from polluted soil (Liu et al. 2016). In addition, topography and meteorological factors may also have an important role in the high accumulation of these elements (Szczepaniak \& Biziuk 2003; Gür \& Yaprak 2011; Dron et al. 2021). 

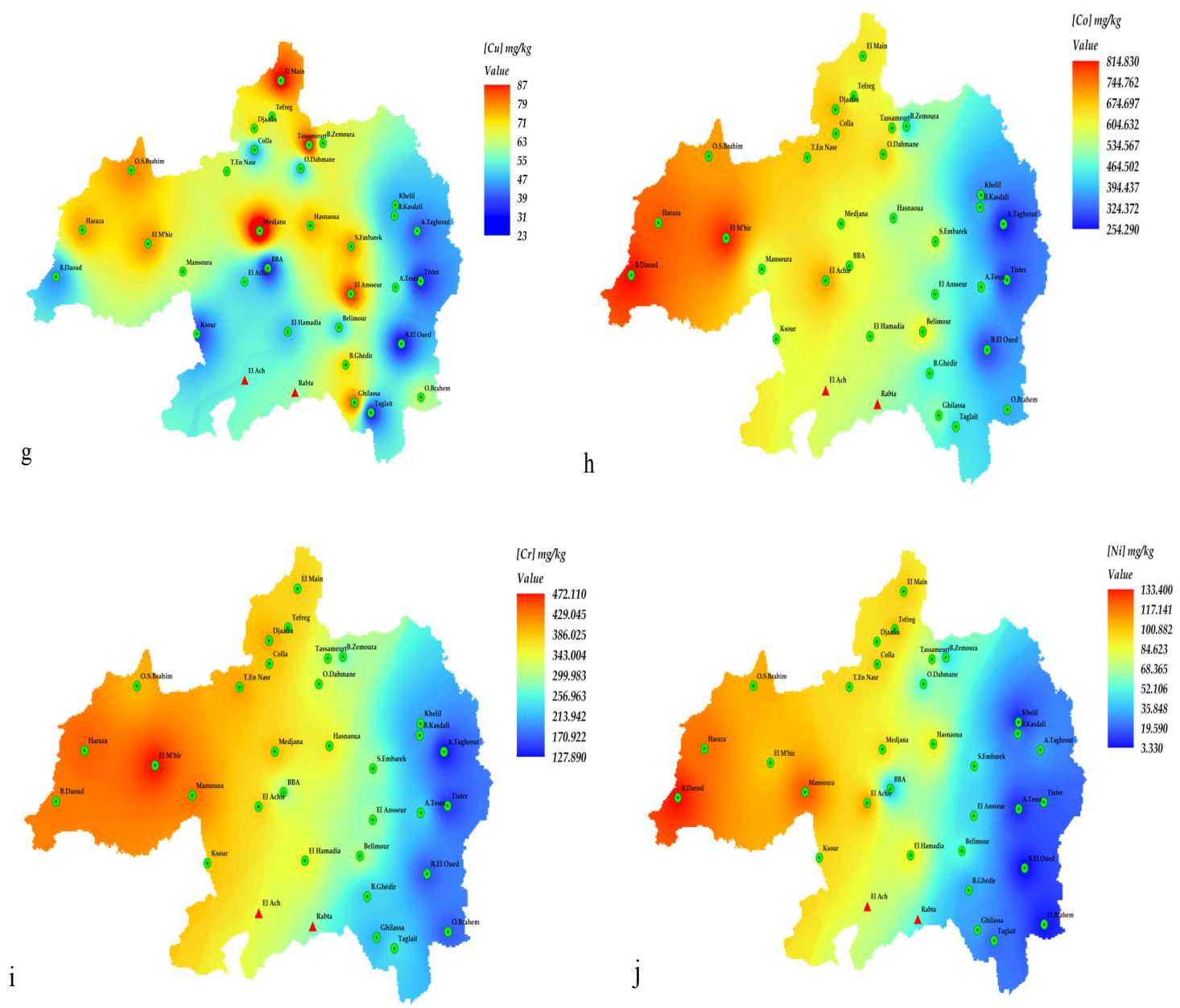

Figure 3. (Continued)

\section{Conclusion}

Element distribution maps were drawn to visualize the spatial distribution of accumulated MTE concentrations in $X$. parietina thalli in the sampling region at BBA, as indicative of different local sources. Road traffic emissions, dust from quarries and building materials, small industries, as well as highly urbanized sites are possible sources of metallic trace elements in the BBA region.

Traffic is a main source of $\mathrm{Pb}, \mathrm{Cd}, \mathrm{Zn}$ and $\mathrm{Sb}$, the abundance of the concentrations of these elements in the studied region decreases from urban sites (high road traffic) towards agricultural sites (low road traffic). Another cause that can explain the high concentrations of $\mathrm{Pb}, \mathrm{Cd}$, and $\mathrm{Sb}$ in the urban stations of the region, would be due to industrial activities.

The highest contributions of elements such as $\mathrm{Fe}, \mathrm{Co}, \mathrm{Mn}, \mathrm{Cr}, \mathrm{Cu}$ and $\mathrm{Zn}$, were observing in the northern and western parts of BBA, especially at sites relatively close to agricultural areas and quarries. For $\mathrm{Ni}$ and $\mathrm{Cr}$ are affected by the soil, but there are obviously other unknown sources around the sites located in the west of the region. The maps made in this study could be a valuable tool for decision-making processes aimed at reducing metal pollution in the study area.

\section{Acknowlegements}

This work was supporting by the laboratory team of the chemistry department, Ferhat abbas setif-1 University and the team of the national company of electrochemical products setif. I would also like to thank Pr. Ramdani Messaoud and Mr. Kouachi Mostefa for their invaluable help in this work.

\section{References}

Agnan Y., (2013), Bioaccumulation et bioindication par les lichens de la pollution atmosphérique actuelle et passée en métaux et en azote en France: sources, mécanismes et facteurs d'influence. Thèse de doctorat. L'université de Toulouse, France, 307 p.

Azimi S., Rocher V., Muller M., Moilleron R., Thevenot D.R. (2005), Sources, distribution and variability of 
hydrocarbons and metals in atmospheric deposition in an urban area (Paris, France). Science of the Total Environment, 337, 223-239.

Aslan A., Cicek A., Yazici K., Karagoz Y., Turan M., Akkus F Yildirim O.S. (2011), The assessment of lichens as bioindicator of heavy metal pollution from motor vehicles activites. African Journal of Agricultural Research 6(7), 1698-1706.

Branquinho C., Brown D.H., Máguas C., Catarino F. (1997), Lead (Pb) uptake and its effects on membrane integrity and chlorophyll fluorescence in different lichen species. Environmental and Experimental Botany, $37,95-105$.

Branquinho C., Gaio-Oliveira G., Augusto S., Pinho P., Maguas C., Correia O. (2008), Biomonitoring spacial and temporal impact of atmospheric dust from a cernent industry. Environmental Pollution, 151, 292-299.

Conti M.E. and Cecchetti G. (2001), Biological monitoring: lichens as bioindicators of air pollution assessmenta review. Environmental Pollution, 114(3), 471-492.

Conti M.E. (2008), Lichens as bioindicators of air pollution. WIT Transactions on State of the Art in Science and Engineering, 30, 111-162.

Cuny D. (2012), La bio-surveillance végétale et fongique de la pollution atmosphérique: concepts et applications. Annales Pharmaceutiques Françaises, 70, 182-187.

De $\mathrm{T}$ emmerman L., Bell J.N.B., Garrec J.P., Klumpp A., Krause G.H.M., Tonneijck A.E.G. (2004), Biomonitoring of air pollutants with plants-considerations for the future. In: Klumpp A., Ansel W., Klumpp G., (Eds.). Urban Air Pollution, bioindication and environmental awareness. Göttingen, Cuvillier Verlag, pp 337-374.

Demiray A.D., Yolcubal I., Akyol N.H., Çobanğlu G. (2012), Biomonitoring of airborne metals using the Lichen Xanthoria parietina in Kocaeli Province, Turkey. Ecological Indicators, 18, 632-643.

Dörter M., Karadeniz H., Saklangıç U., Yenisoy-Karakaş S. (2020), The use of passive lichen biomonitoring in combination with positive matrix factor analysis and stable isotopic ratios to assess the metal pollution sources in throughfall deposition of Bolu plain, Turkey. Ecological Indicators, 113 (106212), 1-10.

Dron J., Austruy A., Agnan Y., Ratier A., Chamaret P. (2016), Utilisation de la biosurveillance lichénique sur la zone industrialo-portuaire de Fos-sur-Mer: retour sur trois ans de suivi à l'échelle d'un territoire intercommunal. Pollution atmosphérique, 228, 1-14.

Dron J., Ratier A., Austruy A., Revenko G., Chaspoul F., Wafo E. (2021), Effects of meteorological conditions and topography on the bioaccumulation of PAHs and metal elements by native lichen (Xanthoria parietina). Journal of environmental sciences, 109, 193-205.

Gür F. and Yaprak G. (2011), Biomonitoring of metals in the vicinity of Soma coalfired power plant in western Anatolia, Turkey using the epiphytic lichen, Xanthoria parietina. Journal of Environmental Science and Health, Part A 46, 1503-1511.

Francovà A., Chrastný V., Sillerovà H., Vitkovà M., Kocourkovà J., Komàrek M. (2017), Evaluating the suitability of different environmental samples for tracing atmospheric pollution in industrial areas. Environmental Pollution, 220(A), 286-297.

Garrec J.P. and Van Haluwyn Ch. (2002), Biosurveillance végétale de la qualité de l'air, concepts, methods et applications. Editions Tec \& doc, Lavoisier, Paris, 118 p.

Gouzy A. and Ducos G. (2008), La connaissance des éléments traces métalliques: un défit pour la gestion de l'environnement. Air Pur, 75, 6-10.

Gombert S., Galsomies L., Rausch de Traubenberg, C., Leblond S., Losno R., Colin J.L., Charée B. (2005), Pollution atmosphérique par les métaux: biosuveillance des retombées. Les Ullis, Angers, EDP Sciences, ADEME, 108 p.

Kinalioglu K., Ozbucak T.B., Kutbay H.G., Huseyinova R., Bilgin A., Demirayak A. (2010), Biomonitoring of Trace Elements with Lichens in Samsun City, Turkey. Ekoloji, 19(75), 64-70.

Li O., Cheng H., Zhou T., Lin Ch., Guo Sh. (2012), The estimated atmospheric lead emissions in China, 19902009. Atmospheric Environment, 60, 1-8.

Liu H-J., Zhao L-Ch., Fang S-B., Liu S-W., Hu J-S, Wang L., Liu X-D., Wu Q-F. (2016), Use of the lichen Xanthoria mandschurica in monitoring atmospheric elemental deposition in the Taihang Mountains, Hebei, China. Scientific Reports, 6(23456), 1-9.

Lin Y.P., Chang T.K., Chiung-Wen Shih C.W., Tseng C.H. (2002), Factorial and indicator kriging methods using a geographic information system to delineate spatial variation and pollution sources of soil heavy metals. Environmental Geology, 42, 900-909.

Loppi S. (2019), May the Diversity of Epiphytic Lichens Be Used in Environmental Forensics? Diversity, 11(36), $1-13$.

Loppi S., Frati L., Paoli L., Bigagli V., Rossetti C., Bruscoli C., Corsini A. (2004), Biodiversity of epiphytic lichens and heavy metal contents of Flavoparmelia caperata thalli as indicators of temporal variations of air pollution in the town of Montecatini Terme (central Italy). Science of the Total Environment, 326, 113-122. 
Markert B.A., Oehlmann J., Roth M. (1997), General aspects of heavy metal monitoring by plants and animals. In: Subramanian G., Iyengar V. (Eds.). Bioindicators \& biomonitors - exposure assessment and specimen banking. ACS Symposium Series, Washington DC: American Chemical Society, 654, 19-29.

Mulgrew A and Williams P. (2000), Biomonitoring of Air Quality Using Plants. Air Hygiene Report 10. WHO Collaborating Centre for Monitoring and Assessment, Germany, $171 \mathrm{p}$.

Nash III T.H. (2008). Lichen Biology. Second Edition, Cambrige, USA, Cambridge University Press, New York, $486 \mathrm{p}$.

Nimis P.L., Andreussi S., Pittao E. (2001), The performance of tow lichen species as bioaccumulators of trace metals. Sci. Total Environ., 275, 43-51.

Nimis P.L., Scheidegger Ch., Wolsely P.A. (2002), Monitoring with lichens-Monitoring lichens. NATO Science Series IV. Earth and Environmental Sciences, vol 7, Springer Netherlands 408 p.

Ouali-Alami F.Z., Elabidi A., Mouhir L., Fekhaoui M., Serghini A. (2014), Utilisation des lichens comme bioindicateurs de la pollution atmosphérique par le plomb, cadmium et zinc de la région de Rabat-SaleZemmour-Zaêr (Maroc). Afrique Science, 10(3), 89-106.

Parzych A., Astel A., Zdunczyk A., Surowiec T. (2016), Evaluation of urban environment pollution based on the accumulation of macro- and trace elements in epiphytic lichens. Journal of Environmental Science and Health, 51(4), 297-308.

Pacyna J.M. and Pacyna E.G. (2001), An assessment of global and regional emissions of trace metals to the atmosphere from anthropogenic sources worldwide. Environmental Reviews, 9, 269-298.

Picardie C.N. (2004), Comparaison de méthodes d'analyse des éléments traces métalliques (ETM) et des hydrocarbures Aromatiques Polycycliques (HAP) sur les sols et les végétaux. Centre d'études sur les réseaux, les transports, l'urbanisme et les constructions publiques (CERTU), France, $120 \mathrm{p}$.

Pignata M.L., Gudiǹo G.L., Wannaz E.D., Plă R.R., Gonzâlez C.M., Carreras H.A., Orellana L. (2002), Atmospheric quality and distribution of heavy metals in Argentina employing Tillandsia capillaris as a biomonitor. Environmental Pollution, 120, 59-68.

Quevauviller Ph., Herzig R., Muntau H. (1996), Certified reference material of lichen (CRM 482) for the quality control of trace element biomonitoring. Sci.Total Environ. 187,143-152.

Rauch J. N. and Pacyna J. M. (2009), Earth's global Ag, Al, Cr, Cu, Fe, Ni, Pb, and Zn cycles. Global Biogeochemical Cycles, 23, 1-16.

Rzepka M.A. and Cuny D. (2008), Biosurveillance Végétale et Fongique des ETM Atmosphériques. Air Pur, 75, 66-79.

Scerbo R., Ristori T., Possenti L., Lampuganini L., Barale R., Barghgiani C. (2002), Lichen (Xanthoria parietina) biomonitoring of trace element contamination and air quality assessment in pisa province (Tuscany, Italy). Sci. Total Enviro., 286, 27-40.

Sett R. and Kundu M. (2016). Epiphytic Lichens: Their Usefulness as Bio-indicators of Air Pollution. Donnish Journal of Research in Environmental Studies, 3(3), 17-24.

Sen I.S. and Peucker-Ehrenbrink B. (2012), Anthropogenic Disturbance of Element Cycles at the Earth's Surface. Environmental Science \& Technology, 46, 8601-8609.

Sloof J.E. and Wolterbeek B.TH. (1993), Interspecies Comparison of Lichens as Biomonitors of Trace - Element Air Polluton. Environmental Monitoring and Assessment, 25, 149-157.

Shukla V., Upreti D.K., Bajpai R. (2014), Lichens to Biomonitor the Environment. Springer India, 195 p.

Szczepaniak K. and Biziuk M. (2003), Aspects of the biomonitoring studies using mosses and lichens as indicators of metal pollution. Environmental Research, 93, 221-230.

Tian H. Z., Zhu C. Y., Gao J. J., Cheng K., Hao J. M., Wang K.,. Hua S. B, Wang Y., Zhou J. R. (2015), Quantitative assessment of atmospheric emissions of toxic heavy metals from anthropogenic sources in China: historical trend, spatial variation distribution, uncertainties and control policies. Atmos. Chem. Phys. Discuss., 15, 12107-12166.

Wolterbeek B. (2002). Biomonitoring of trace element air pollution: principles, possibilities and perspectives. Environmental Pollution, 120, 11-21.

Wolterbeek H.T., Garty J., Reis M.A., Freitas M.C. (2003), Biomonitors in use: lichens and metal air pollution. In: Markert B.A., Breure A.M., Zechmeister H.G. (Eds.). Bioindication and Biomonitoring. Elsevier Science Ltd., Oxford, pp 377-419.

Wu Y-y., Gao J., Zhang G-z., Zhao R-k., Liu A-q., Sun L-w., Li X., Tang H-l., Zhao L-ch., Guo X-p., Liu H-j. (2020), Two lichens differing in element concentrations have similar spatial patterns of element concentrations responding to road traffic and soil input. Scientific Reports, 10 (19001), 1-11.

Yenisoy-Karakas S., Tuncel S.G. (2004), Geographic patterns of elemental deposition in the Aegean region of Turkey indicated by the lichen, Xanthoria parietina (L.) Th. Fr. Science of the Total Environment, 329, 4360. 